\title{
Hematologi rutin sapi peranakan ongole yang mengalami mumifikasi fetus ${ }^{\dagger}$
}

\author{
Dinar Arifianto ${ }^{1, *}$, Topas Wicaksono Priyo $\mathrm{Jr}^{2}$, Erif Maha Nugraha Setyawan², Agus Purnomo ${ }^{3}$, \\ Dhirgo Adji ${ }^{3}$, Yuriadi ${ }^{4}$ \\ ${ }^{1}$ Departemen Patologi Klinik, Fakultas Kedokteran Hewan, Universitas Gadjah Mada, Yogyakarta \\ ${ }^{2}$ Departemen Reproduksi dan Obstetri, Fakultas Kedokteran Hewan, Universitas Gadjah Mada, Yogyakarta \\ ${ }^{3}$ Departemen Ilmu Bedah dan Radiologi, Fakultas Kedokteran Hewan, Universitas Gadjah Mada, Yogyakarta \\ ${ }^{4}$ Departemen Ilmu Penyakit Dalam, Fakultas Kedokteran Hewan, Universitas Gadjah Mada, Yogyakarta
}

\begin{abstract}
ABSTRAK: Seekor sapi peranakan ongole dilaporkan melewati batas waktu perkiraan kelahiran pada bulan ke-10 tanpa menunjukkan adanya tanda-tanda mendekati kelahiran. Pemeriksaan ultrasonografi dilakukan untuk memastikan kondisi kebuntingan dan didapatkan gambaran dinding uterus bersinggungan dengan bentukan tulang dan teracak fetus serta cairan amnion yang sangat sedikit dan hampir mengering. Pemeriksaan fisik dan pengambilan sampel darah dilakukan untuk memperkuat diagnosis dan melakukan rencana terapi. Operasi caesar dilakukan untuk mengeluarkan fetus melalui prosedur operasi posisi berdiri pada flank kiri. Fetus berwarna coklat kekuningan dan mengalami perlekatan dengan kotiledon serta membran khorioalantois. Hasil gambaran darah sebelum operasi menunjukkan hasil nilai eritrosit, $\mathrm{Hb}, \mathrm{MCV}, \mathrm{MCH}$, total leukosit, neutrofil, limfosit, monosit, eosinofil, total protein plasma dan fibrinogen dalam batas normal. Trombosit dan MCHC mengalami penurunan sedangkan PCV mengalami peningkatan.
\end{abstract}

\section{Kata kunci:}

fetus, hematologi, mumifikasi, peranakan ongole, sapi

\section{- PENDAHULUAN}

Insidensi mumifikasi fetus pada sapi tercatat sebanyak $0,13-$ $1,8 \%$ dan biasanya terjadi pada usia kebuntingan 3-8 bulan (Kumar et al. 2017; Arthur et al. 1996). Agen infeksius seperti Campylobacter foetus, jamur, leptospirosis serta virus BVD-MD dapat menyebabkan kematian fetus tanpa disertai luteolisis dan berlanjut pada kejadian mumifikasi fetus (Drost 2017; Thomas 2007). Terapi mumifikasi dapat dilakukan dengan pemberian PGF2 $\alpha$, stilbestrol, estradiol, repositol diethylstilbestrol, atau dengan menghilangkan corpus luteum. Prosedur intervensi dengan operasi colpotomy atau hysterectomy/caesar dapat dilakukan jika prosedur terapi mumifikasi fetus tidak dapat dilakukan (Azizunnesa et al. 2010).

Mumifikasi dapat berkembang menjadi maserasi akibat kegagalan pengeluaran fetus dan inersia uteri. Diagnosis mumifikasi fetus dapat dilakukan dengan pemeriksaan ultrasonografi dan dapat diperkuat dengan data pemeriksaan klinis dan gambaran darah. Rendahnya kasus membuat data dan informasi mengenai pemeriksaan hematologi pada sapi yang mengalami mumifikasi fetus tidak banyak ditemukan.

\section{KASUS}

Riwayat: Sapi berjenis peranakan ongole (PO) berumur 3 tahun telah dilakukan pemeriksaan kebuntingan dan diperkirakan umur kebuntingan adalah 3 bulan. Setelah usia kebuntingan memasuki bulan ke-10 tidak tampak gejala perkembangan ukuran abdomen dan tanda-tanda mendekati kelahiran sehingga dilakukan pemeriksaan ultrasonografi (Gambar S1).

Pemeriksaan Fisik dan Hematologi: Pemeriksaan fisik dilakukan dengan inspeksi serta menggunakan alat bantu stetoskop dan termometer. Darah diambil melalui vena coxygea sebanyak $3 \mathrm{ml}$ dan ditampung dalam tabung EDTA. Pemeriksaan darah meliputi parameter eritrosit, parameter leukosit, total protein plasma (TPP), dan fibrinogen. Prosedur penelitian telah mendapatkan sertifikat kelayakan etik dari Komite Etik Fakultas Kedokteran Hewan UGM dengan nomor sertifikat 0041/EC-FKH/Int./2020.

Operasi Caesar: Operasi caesar dilakukan melalui flank kiri dengan posisi berdiri menggunakan kombinasi anestesi epidural dan L-block (Gambar S2). Setelah insisi kulit, muskulus dan peritoneum, cornua uteri sebelah kiri yang berisi fetus dibalut dengan kasa yang dibasahi dengan antibiotik. Selanjutnya uterus diinsisi dan fetus dikeluarkan. Tunika mukosa uterus lalu dibersihkan dari cairan sisa fetus dan kotiledon yang melekat dibuang. Uterus dan kulit

Diterima: 30-12-2020 | Direvisi: 29-01-2021 | Disetujui: 01-02-202 (C) 2021 CC-BY-SA. Ini adalah artikel Open Access yang didistribusikan berdasarkan ketentuan dari Creative Commons Attribution ShareAlike 4.0 International License (https://creativecommons.org/licenses/by-sa/4.0/). 
kemudian dijahit. Setelah operasi sapi diinjeksi dengan antibiotik, vitamin, dan analgesik. Injeksi antibiotik dan vitamin diulang setelah 2 hari. Luka dibersihkan dengan iodin povidon $3 \%$ dan disemprot dengan antiseptik dan antilarva. Luka pada kulit tampak membaik pada hari ke-10 dan jahitan diambil.

\section{HASIL DAN PEMBAHASAN}

Pemeriksaan fisik sapi menunjukkan nafsu makan dan minum baik. Frekuensi napas 32 kali per menit. Frekuensi pulsus 72 kali per menit. Temperatur rektal $38,7^{\circ} \mathrm{C}$. Gerak rumen 7 kali per 5 menit dengan tonus rumen kuat. Pemeriksaan umum pada sapi yang mengalami mumifikasi fetus akan tampak normal. Pemeriksaan ultrasonografi menunjukkan adanya massa padat dan tidak tampak cairan amnion yang seharusnya tampak hipoekhoik.

Pemeriksaan hematologi menunjukkan parameter leukosit masih dalam batas normal (Tabel 1). Penurunan terjadi pada parameter MCHC dan trombosit. Trombositopenia dapat terjadi karena hilangnya trombosit dalam jumlah besar, berkurangnya produksi trombosit, kerusakan trombosit, dan gangguan distribusi trombosit (Roland et al. 2014). Kenaikan PCV relatif tampak pada gambaran darah dan tidak disertai dengan kenaikan jumlah eritrosit. Kenaikan jumlah PCV dapat disebabkan karena menurunya jumlah plasma pada individu yang mengalami dehidrasi (Roland et al. 2014). Parameter eritrosit selain MCHC dan PCV menunjukkan nilai normal.

Tabel 1 Gambaran darah sapi dengan mumifikasi fetus

\begin{tabular}{lcccc}
\hline Parameter & Hasil & Satuan & $\begin{array}{c}\text { Nilai } \\
\text { Normal }\end{array}$ & Keterangan \\
\hline Eritrosit & 8,17 & $10^{6} / \mu \mathrm{L}$ & $5-10$ & Normal \\
$\mathrm{Hb}$ & 10,9 & $\mathrm{~g} / \mathrm{dL}$ & $9-14$ & Normal \\
$\mathrm{PCV}$ & 39,03 & $\%$ & $28-38$ & Meningkat \\
$\mathrm{MCV}$ & 48 & $\mathrm{fL}$ & $46-65$ & Normal \\
$\mathrm{MCH}$ & 13,3 & $\mathrm{pg}$ & $11-17$ & Normal \\
$\mathrm{MCHC}$ & 27,9 & $\mathrm{~g} / \mathrm{dL}$ & $31-34$ & Menurun \\
Trombosit & 120 & $10^{3} / \mu \mathrm{L}$ & $300-800$ & Menurun \\
TPP & 7,8 & $\mathrm{~g} / \mathrm{dL}$ & $56,9-7,86$ & Normal \\
Fibrinogen & 500 & $\mathrm{mg} / \mathrm{dL}$ & $320-1350$ & Normal \\
WBC & 6,68 & $10^{3} / \mu \mathrm{L}$ & $5-10$ & Normal \\
Limfosit & 4,94 & $10^{3} / \mu \mathrm{L}$ & $2,5-5,5$ & Normal \\
Monosit & 0,09 & $10^{3} / \mu \mathrm{L}$ & $0,0-0,03$ & Normal \\
Neutrofil & 1,27 & $10^{3} / \mu \mathrm{L}$ & $1,0-3,5$ & Normal \\
Eosinofil & 0,38 & $10^{3} / \mu \mathrm{L}$ & $0,3-1,5$ & Normal \\
Basofil & 0,0 & $10^{3} / \mu \mathrm{L}$ & $0,0-0,1$ & Normal \\
\hline
\end{tabular}

Nilai normal menurut Kraft \& Dürr, (2005); McSherry et al. (1970);

Alberghina et al. (2011); Roland et al. (2014).

Kondisi fetus setelah dikeluarkan berwarna coklat dengan tubuh yang mengering, bola mata menghilang, dan tidak terdapat bagian tubuh yang terpisah. Kematian fetus tanpa inisiasi kelahiran dapat menyebabkan corpus luteum (CL) tidak mengalami regresi. Kebuntingan akan dipertahankan sampai waktu yang tidak dapat ditentukan karena CL mensekresikan cukup progesteron untuk memelihara kebuntingan dan seringkali baru terdiagnosis karena masa kebuntingan yang berkepanjangan (Arthur et al. 1996).

\section{SIMPULAN}

Kasus mumifikasi fetus pada sapi peranakan ongole dapat didiagnosis secara ultrasonografi dengan ditemukannya bagian tubuh fetus, dinding uterus yang bersinggungan dengan fetus, dan hilangnya cairan amnion. Gambaran darah menunjukkan hasil $\mathrm{Hb}, \mathrm{MCV}, \mathrm{MCH}$, parameter leukosit, TPP, dan fibrinogen yang normal. Trombosit dan MCHC mengalami penurunan sedangkan PCV mengalami peningkatan. Proses autolisis yang terjadi saat mumifikasi fetus tidak direspon sebagai infeksi oleh tubuh yang tampak pada gambaran darah.

\section{- INFORMASI PENDUKUNG}

$\uparrow$ Sonogram dan dokumentasi kasus tersedia sebagai informasi pendukung.

\section{INFORMASI PENULIS}

\section{Penulis Korespondensi}

*DA: dinar.arifianto@ugm.ac.id

Departemen Patologi Klinik Fakultas Kedokteran Hewan Universitas Gadjah Mada, Yogyakarta

\section{- UCAPAN TERIMA KASIH}

Ucapan terima kasih diucapkan kepada Unit Pendidikan dan Pelatihan Kesehatan Hewan, Departemen Ilmu Bedah dan Radiologi, Departemen Reproduksi dan Obstetri, Departemen Ilmu Penyakit Dalam, dan Departemen Patologi Klinik Fakultas Kedokteran Hewan Universitas Gadjah Mada.

\section{PUSTAKA ACUAN}

Alberghinan D, Giannetto C, Vazzana I, Ferrantelli V, Piccione G. 2011. Reference intervals for total protein concentration, serum protein fractions, and albumin/globulin ratios in clinically healthy dairy cows. Journal of Veterinary Diagnostic Investigation. 23(1): 111-114.

Arthur GH. Noakes DE. Person H, Parkinson TJ. 1996. Sequelae to embryonic or foetal death. In: Veterinary Reproduction and Obstetrics. $7^{\text {th }}$ ed.. Philadelphia; W.B. Saunders: 127-128.

Azizunnesa BC, Sutradhar BC, Das MF, Hossain and Faruk MO 2010. A Case Study on Mummified Foetus in A Heifer. University Journal of Zoology Rajshahi University. 28: 61-63.

Drost M. 2007. Complications during gestation in the cow. Theriogenology. 68(7): 487-491.

Kraft W, Dürr UM. 2005. Klinische Labordiagnostik in der Tiermedizin. $6^{\text {th }}$ ed. Stuttgart: Schattauer Verlag.

Kumar PR, Prasad BC, Bose GSC, Prasad VD, Sreenu M. 2017. Diagnosis and Management of Fetal Mummification in Cow. International Journal of Science Environment and Technology. 6(5): 3044-3048.

McSherry BJ, Horney FD, deGroot JJ. 1970. Plasma Fibrinogen Levels in Normal and Sick Cows. Canadian Journal of Comparative Medicine. 34: 191-197.

Roland L, Drillich M, Iwersen M. 2014. Hematology as a diagnostic tool in bovine medicine. Journal of Veterinary Diagnostic Investigation. 26 (5): 592-598

Thomas PGA 2007. Induced abortion. In: Current therapy in large animal theriogenology. $2^{\text {nd }}$ edition. Youngquist RS, Threlfall WR, editor. Missouri: Elsevier. 